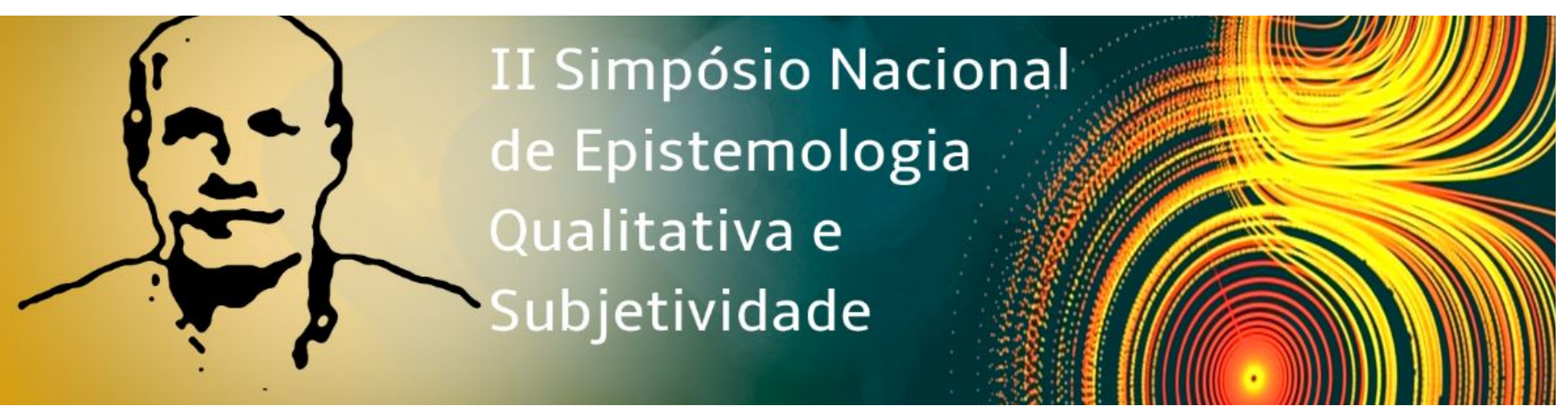

Eixo temático: Subjetividade e Saúde humana

\title{
Protagonismo dos Usuários de Saúde Mental no Cenário Brasileiro Atual
}

Daniela Viecili Costa Masini, UniCeub, daniviecilicm@gmail.com Daniel Magalhães Goulart, UniCeub, danielgoulartbr@gmail.com

\section{Resumo}

Este trabalho tem como objetivo apresentar as ideias centrais que compõem um projeto de pesquisa de Iniciação Científica do curso de Psicologia do Centro Universitário de Brasília, que visa compreender a configuração subjetiva social dominante em um grupo de pessoas em sofrimento psíquico integrantes de um grupo de ajuda mútua. A problemática que inspirou essa pesquisa é a prevalência do profissional de saúde nos diferentes cenários de saúde mental, em associação com a dificuldade de oferecer um cuidado que favoreça o desenvolvimento subjetivo dos usuários, que por vezes acabam sendo "encapsulados" em serviços de saúde medicalizantes e burocráticos (GOULART, 2017). O foco deste trabalho é discutir os diversos aspectos sociais e culturais implicados na manutenção dos usuários num lugar de passividade, desfavorável à geração de recursos subjetivos alternativos àqueles associados ao seu sofrimento (GONZÁLEZ REY, 2011). A dificuldade de participação dos usuários - em contraste com a hipervalorização cultural e econômica da atuação dos profissionais de saúde - se expressa tanto no cotidiano dos serviços de saúde quanto no âmbito político, e pode estar associada não apenas ao estigma da "loucura", mas também a um cenário de intensa desigualdade social e a uma cultura hierárquica, que dificultam o ativismo político de pessoas oriundas de classes socioeconômicas menos privilegiadas (VASCONCELOS, 2000; NEUBERN, 2012). Numa perspectiva mais ampla, pode-se dizer que são poucos os espaços sociais que permitem uma postura mais ativa por parte das pessoas (SOUZA, 2017). Numa sociedade do consumo em que a mídia e o modelo biomédico têm um importante papel na construção de formas de viver e pensar, em que o sistema de ensino é eminentemente bancário, não são apenas as pessoas com transtornos mentais que estão de certa forma submetidas a um lugar de passividade - apesar de que, no caso 


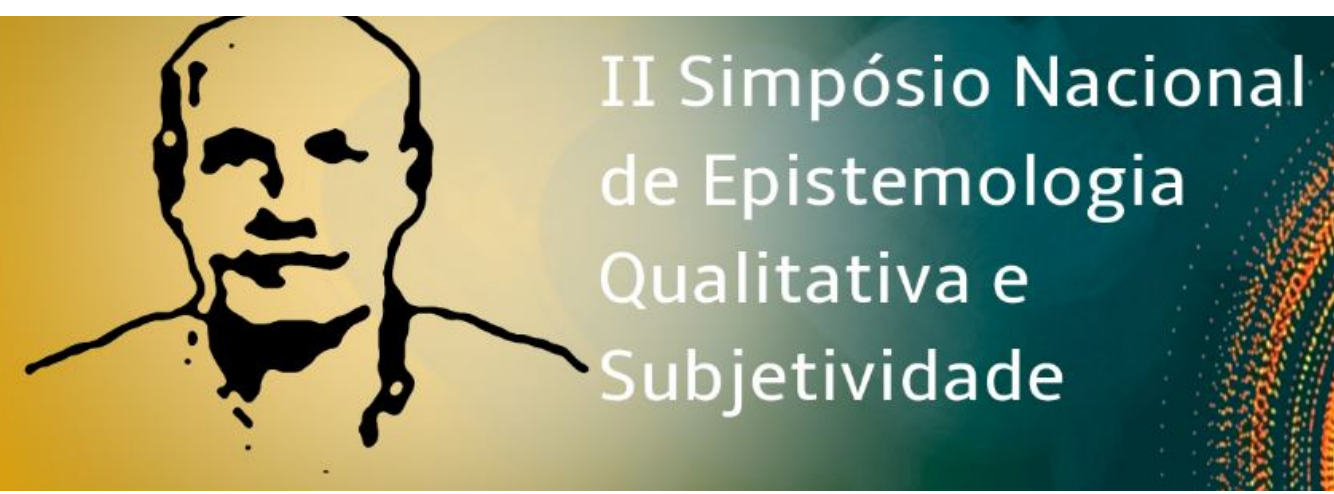

destas, isso se tornou mais uma fonte de sofrimento. No contexto brasileiro, aliam-se a isso, ainda, uma tradição democrática recente e um penoso processo de construção da cidadania (CARVALHO, 2001). Diante disso, pode-se questionar: quais as possíveis relações desse contexto com o sofrimento psíquico do brasileiro na atualidade, considerando a noção de sujeito na teoria da subjetividade?

Palavras chave: saúde mental, subjetividade, sujeito.

\section{Referências}

GONZÁLEZ REY, L. F. Subjetividade e Saúde: superando a clínica da patologia. São Paulo: Cortez, 2011.

GOUlART, D. M. Educação, Saúde Mental e Desenvolvimento Subjetivo: da patologização da vida à ética do sujeito. 2017. 254f. Dissertação (Doutorado em Educação) - Universidade de Brasília, Brasília, 2017.

NEUBERN, M. Ensaio sobre a cegueira de Édipo: sobre psicoterapia, política e conhecimento. In: HOLANDA, A. F. (Org.). O Campo das Psicoterapias: reflexões atuais. Curitiba: Juruá, 2012. p. 13-45.

SOUZA, J. M. Escola! Cuidado crianças: o cotidiano escolar e as (im)possibilidades de educação libertadora. 2017. 210 f. Tese (Doutorado em Educação) - Universidade de Brasília, Brasília, 2017.

VASCONCELOS, E. M. Reinvenção da Cidadania, Empowerment no Campo da Saúde Mental e Estratégia Política no Movimento de Usuários. In: AMARANTE, P. (Org.). Ensaios: subjetividade, saúde mental, sociedade. Rio de Janeiro: FIOCRUZ, 2000. p. 169-194. CARVALHO, J. M. Cidadania no Brasil: o longo caminho. Civilização Brasileira: São Paula, 2001. 